\title{
O capital acionário e sua necessidade: elementos para a compreensão do processo de financeirização da firma *
}

\author{
Bruno Höfig * \\ Não se trata (...) de definições sob as quais as coisas são subsumidas. Trata- \\ se de funções, as quais são exprimidas em categorias determinadas.
}

(Karl Marx. O Capital, Livro II).

\begin{abstract}
Resumo
O artigo examina o processo histórico de autonomização do capital acionário em relação ao circuito do capital empregado na produção e circulação de mercadorias. Com esse fim, ele apresenta sinteticamente a abordagem de Marx ao problema da relação entre ação individual e estrutura social na economia capitalista, e reconstitui suas reflexões acerca do capital portador de juros e do capital acionário. O artigo mostra que o capital acionário é uma forma social que emerge da contradição entre o caráter privado da riqueza capitalista e o impulso interno à socialização da atividade econômica desempenhada sob condições capitalistas. Com base nisso, ele explora a hipótese de que a autonomização relativa do capital acionário não deve ser compreendida como um resultado contingente de decisões mais ou menos arbitrárias, mas sim como um resultado necessário do desenvolvimento histórico do modo de produção capitalista.
\end{abstract}

Palavras-chave: Financeirização; Capital acionário; Capital fictício; Capital portador de juros; Desregulamentação.

\begin{abstract}
The necessity of share capital: notes on the financialisation of firms

This paper examines the historical process of autonomization of share capital in relation to the circuit of capital effectively employed in the production and circulation of commodities. To this end, it presents the Marxian approach to the relationship between agency and structure in a capitalist economy, and reconstructs his analysis of the forms of interest bearing capital and share capital. The paper shows that share capital emerges from the contradiction between the private character of the capitalist wealth and the internal impulse towards the socialization of economic activity. Based on this, it explores the hypothesis that, far from being a contingent outcome of the apparently autonomous decisions made by the individuals that participate in this process, such relative autonomization is actually a necessary outcome of the historical development of the capitalist mode of production.
\end{abstract}

Keywords: Financialization; Share capital; Fictitious capital; Interest-bearing capital; Deregulation. JEL B14, B51, G30, N10, N20.

* Artigo recebido em 31 de março de 2017 e aprovado em 18 de setembro de 2017.

${ }^{* *}$ Doutorando em Economia na Soas (Universidade de Londres), Londres, UK. O autor registra seus agradecimentos a um parecerista anônimo, por suas valiosas sugestões, e a Jorge Grespan, Alfredo Saad Filho, Iderley Colombini e Pedro Mendes, pela leitura crítica de diferentes versões deste texto. Os erros remanescentes, obviamente, são de inteira responsabilidade do autor. E-mail: bhofig@gmail.com. 
Em uma das mais conhecidas definições do conceito que tematiza esta edição especial de Economia e Sociedade, Gerard Epstein (2006, p. 3) afirma que "financeirização significa o papel crescente de motivos financeiros, mercados financeiros, atores financeiros e instituições financeiras na operação das economias domésticas e internacionais". Tal definição prima pela abrangência; esta, contudo, cobra um alto preço: a falta de precisão. Ao menos no que se refere à maior economia capitalista contemporânea (a dos Estados Unidos, a qual costuma servir de modelo à maioria das teorias da financeirização), o crescimento do papel das finanças se faz observar em fenômenos prima facie bastante diferentes: do crescimento do setor de serviços financeiros ao crescimento dos lucros associados a atividades financeiras (Krippner, 2005); da crescente importância dos planos privados de aposentadoria (Langley, 2009) ao crescente papel do crédito na determinação do consumo (Montgomerie, 2008); da exacerbação do processo de capitalização (Fine, 2013; Leyshon; Thrift, 2007) à expropriação financeira que fomenta a redução indireta do valor da força de trabalho (Lapavitsas, 2013); e assim por diante. Existe, porém, um elemento comum entre os membros da quase infinita série de fenômenos associados à noção de financeirização: todos eles parecem estar, de alguma maneira, relacionados à queda da taxa de acumulação observada nas principais economias capitalistas ocidentais desde os anos 1970.

Poucas análises revelaram com tanta clareza os mecanismos que ligam as operações dos mercados, atores e instituições financeiras à redução do ritmo da acumulação quanto aquelas que, estabelecendo os fundamentos microeconômicos da financeirização, vincularam esse processo a transformações ocorridas no modo de funcionamento da grande corporação capitalista (Aglietta, 2000; Aglietta; Reberioux, 2005; Boyer, 2005; Chesnais, 2006; Crotty, 2003; Dallery, 2009; Duménil; Lévy, 2013; Lazonick; O’Sullivan, 2000; Stockhammer, 2004). De acordo com essa abordagem, a queda do ritmo da acumulação teria sido causada pela redução do volume e da qualidade dos investimentos produtivos realizados por essas empresas - a qual, por sua vez, seria um efeito da crescente preocupação de seus administradores com os movimentos dos preços de suas ações nos mercados secundários (Davis, 2011).

Tal preocupação, vale lembrar, era estranha ao tipo de organização empresarial que se desenvolveu e disseminou nos EUA na primeira metade do século XX. De fato, como mostrou Alfred Chandler (1993), um dos mais importantes efeitos da revolução gerencial (managerial revolution) pela qual passou a firma capitalista naquele período foi a autonomização dos gestores profissionais frente aos acionistas das empresas por eles administradas. Fortalecidos pelo crescimento de sua influência sobre o processo decisório, os administradores puderam privilegiar muitas vezes em detrimento dos lucros correntes e da distribuição de dividendos as estratégias que maximizavam os resultados de longo prazo das empresas por eles 
administradas (Chandler, 1993, p. 10; ver também Berle; Means, 1984; Galbraith, 1968), negligenciando em boa medida os efeitos de suas decisões sobre os movimentos de curto prazo dos preços das ações por elas emitidas. Esse estado de coisas, porém, se alterou drasticamente no último quartil do século $\mathrm{XX}$, quando a alta burocracia corporativa passou a dedicar cada vez mais atenção aos movimentos desses preços, os quais por sua vez se autonomizaram progressivamente em relação ao processo de acumulação efetiva de capital - perdendo, assim, a capacidade de exprimir a capacidade da empresa de produzir valor e mais-valor (Sloan, 1996; Zajac; Westphal, 2004). A partir de então, observou-se um desmedido foco da alta burocracia corporativa em resultados financeiros de curto prazo. Consequentemente, as grandes corporações passaram não apenas a elevar a proporção dos lucros distribuída sob a forma de dividendos (Crotty, 2003), diminuindo a parcela retida e comprometendo sua capacidade de investimento, mas também a alocar uma proporção cada vez maior de seus recursos em ativos e atividades de caráter puramente financeiro (Krippner, 2005) e a reduzir o horizonte temporal de realização de seus investimentos produtivos (Lazonick; O’Sullivan, 2000). E isso, segundo os teóricos da financeirização da firma, teria resultado na queda da taxa de investimento e na desaceleração do crescimento da produtividade, fenômenos por sua vez associados à redução do ritmo da acumulação de capital (Stockhammer, 2004), à diminuição da taxa de crescimento da economia e, em última instância, à instabilidade que resultou na catástrofe de 2008 (Stockhammer; Lavoie, 2013, várias contribuições) $)^{2}$.

Quais as causas dessa mudança no modo de operação da grande corporação capitalista? A princípio, tendeu-se a interpretar tal fenômeno como uma consequência da crescente subordinação da burocracia corporativa aos interesses dos acionistas (Boyer, 2005; Davis, 2011; Fligstein; Shin, 2007). O processo ter-se-ia iniciado nos anos 1970, com o desenvolvimento dos grandes investidores institucionais que em boa medida reverteu a dispersão da propriedade inicialmente provocada pelo desenvolvimento da sociedade anônima (Useem, 1999); intensificado-se nos anos 1980, com a disseminação das ofertas hostis de compra

(2) Como sintetizado por Chesnais (1998, p. 261-262): “A aceleração do processo de financeirização dos grupos industriais (...) [teve] efeitos certeiros sobre o investimento. O horizonte temporal da valorização do capital industrial é, cada vez mais, o que tem sido caracterizado (...) de 'short termism'. (...) [Os estudos que tratam do assunto - BH] estigmatizaram os efeitos nocivos sobre o investimento produtivo, tanto material quanto imaterial (pesquisa e desenvolvimento, formação) dos horizontes de valorização impostos pelos mercados financeiros, e muitas vezes acentuados pela entrada de fundos de pensão na esfera de propriedade do capital industrial. (...) [O resultado da financeirização - BH] consistiu em que (...) os horizontes de valorização de muito curto prazo, ditados pelos imperativos financeiros ligados ao andamento das ações nas bolsas e ao medo de ofertas públicas de compra hostis, tendem a caracterizar o tipo de investimento próprio do regime de acumulação mundial predominantemente financeiro. As características do investimento produtivo, do ponto de vista do ritmo, do montante e da orientação setorial (...) levam a formular a hipótese de que, pela primeira vez na história do capitalismo, no centro do sistema, a acumulação do capital não mais se coloca claramente sob o signo da reprodução ampliada". 
que subordinaram a sobrevivência da administração aos movimentos dos preços das ações nos mercados secundários (Baskin; Miranti Jr., 1999, cap. 7; Davis; Stout, 1992); e concluído-se nos anos 1990, com a generalização dos sistemas de remuneração baseados em opções sobre ações, através dos quais os interesses pessoais dos administradores teriam se identificado com os dos acionistas (Chesnais, 2006). À medida porém que os recorrentes escândalos corporativos demonstram a fragilidade da tese da subordinação da burocracia empresarial (Dunn, 2010, p. 9; Lavoie, 2015, p. 131-132), e que a valorização acionária se revela um mecanismo essencial à consolidação do poder de mercado das grandes corporações (Norfield, 2016, p. 90-92) - constituindo, portanto, um dos mais importantes instrumentos para a realização daquela que muitos economistas heterodoxos consideram como a finalidade mesma da firma capitalista (Dallery, 2009; Lavoie, 2015, cap. 3) -, faz-se necessário reconhecer que a financeirização das corporações capitalistas não pode ser atribuída ao poder do acionista enquanto tal. De fato, a adequação das decisões de investimento aos humores do mercado acionário não é o resultado irracional da interferência de interesses estranhos à firma, mas sim um modo de conduta racional num ambiente em que os preços das ações se tornaram em boa medida autônomos em relação ao processo de acumulação de capital enquanto tal - e, particularmente, num contexto de quase contínua inflação dos preços desses ativos em relação aos das mercadorias ordinárias, como o que se tem observado nos EUA desde a década de 1970 (Toporowski, 2009) ( $^{3}$.

É, portanto, sobretudo na autonomização do capital acionário que se deve situar a origem da firma financeirizada. Por conseguinte, se quisermos compreender os fundamentos históricos do capitalismo contemporâneo, é necessário compreender o processo que culminou nessa autonomização. E é aí que se insere a presente contribuição. Mobilizando as reflexões de Marx acerca das determinações das formas sociais características das sociedades em que vigora o modo de produção capitalista, e baseando-se em suas considerações acerca da natureza do capital fictício, o artigo oferece elementos para uma interpretação do recente desenvolvimento do capital acionário que difere da que tem dominado a literatura sobre o tema. Em particular, o artigo explora a hipótese de que, longe de ser um mero resultado das decisões arbitrárias dos indivíduos envolvidos no processo, a autonomização do capital acionário consiste na verdade num resultado necessário do evolver histórico do modo de produção capitalista.

(3) Note-se que o processo em tela é diferente daquele examinado por Hilferding (1981 [1910]) no início do século passado. Embora estejamos diante de uma intensificação da influência dos mercados de capitais sobre as operações da grande corporação capitalista, não se pode falar, no caso atual, de uma dependência do capital industrial em relação aos capitais especializados em fornecer fundos para investimento. Com efeito, a maior parte dos recursos investidos pela grande corporação estadunidense provém de seus próprios lucros (Cecchetti; Schoenholtz, 2014, p. 289; ver também Baran; Sweezy, 1978). 
Tal argumento será desenvolvido em cinco estapas. Na primeira, apresentase criticamente a ideia (bastante difundida na literatura econômica) de que a desregulamentação do setor financeiro foi o resultado intencional de decisões mais ou menos arbitrárias tomadas pelos indivíduos diretamente envolvidos nesse processo. Na segunda, exploram-se as considerações marxianas a respeito do caráter peculiar da conexão entre ação individual e estrutura social nas sociedades em que a troca se impõe como forma geral do intercâmbio material entre os indivíduos, e desenvolve-se a ideia de que as formas funcionais ao processo de reprodução ampliada do capital tendem, em tais sociedades, a emergir espontaneamente das ações parcialmente conscientes dos próprios indivíduos. Em seguida, demonstra-se, através de análise detalhada das reflexões de Marx sobre os processos de concentração e centralização do capital, que o capital acionário é uma forma social imanente ao modo de produção capitalista. Posteriormente, apresentam-se os conceitos de capital portador de juros e capital fictício, e reconstitui-se, a partir das esparsas anotações deixadas por Marx sobre o tema, o conceito de capital acionário. Após desenvolver uma interpretação do recente processo de autonomização do capital acionário baseada nas reflexões de Marx acerca da relação entre agência e estrutura no modo de produção capitalista e em sua análise das determinações fundamentais dessa forma particular do capital, o artigo se encerra com algumas considerações finais.

\section{A abordagem dominante}

O processo de autonomização do capital acionário está intimamente vinculado a certas transformações institucionais iniciadas nos EUA na década de 1970, as quais derrubaram as barreiras que impediam a livre negociação de todo e qualquer tipo de ativo financeiro e isolavam, em alguma medida, os movimentos dos preços das ações emitidas pelas grandes corporações da influência de fatores completamente estranhos ao processo efetivo de reprodução ampliada do capital. Em vista da importância histórica de suas consequências, a interpretação correta de tais eventos mostra-se como um elemento essencial de uma análise adequada do capitalismo contemporâneo. Duas perguntas, em particular, devem ser respondidas: quais as principais características das transformações em tela? E o que as motivou?

De acordo com uma interpretação largamente aceita por pesquisadores associados a diferentes partes do espectro analítico (Helleiner, 2008; Krugman, 2009; Stiglitz, 2009; Wade, 2008), tais transformações devem ser compreendidas como resultado do processo de retirada das amarras com as quais o Estado vinha disciplinando as forças caóticas do mercado financeiro desde a década de $1930^{4}$. Mais precisamente, elas devem ser interpretadas como uma consequência dos

(4) Para uma descrição detalhada dessas reformas, ver Russell (2007). 
processos de desregulamentação e liberalização financeiras, que consistiram, entre outras coisas, na remoção das barreiras que antes isolavam as atividades desempenhadas por bancos comerciais e bancos de investimento (Russell, 2007), na extinção das normas que outrora restringiam os tipos de ativos financeiros que poderiam ser emitidos e limitavam a remuneração a que seus portadores tinham direito (Smith, 2001), e na eliminação dos entraves ao fluxo internacional de capitais estabelecidos pelo sistema de Bretton Woods (D’Arista, 2009; Saes, 2013, cap. 22). Ainda de acordo com essa abordagem, os processos de desregulamentação e liberalização constituíram o resultado intencional de decisões conscientes tomadas pelas autoridades públicas relevantes em momentos cruciais da história econômica recente (Chesnais, 2006), decisões essas que foram motivadas, por um lado, pela crescente influência das ideias neoliberais (Fourcade, 2007; Mirowski, 2013; Peck, 2013) e, por outro, pela nova hegemonia das frações da classe capitalista diretamente ligadas a atividades de cunho exclusivamente financeiro (Crouch, 2009; Saes, 2013, p. 566).

Tal intepretação lança luz sobre processos, agentes e motivações que cumpriram papéis determinantes nas transformações que levaram à autonomização do capital acionário e à gênese da firma financeirizada. No entanto, ela é problemática em ao menos dois sentidos. Em primeiro lugar, como sugere Konings (2009, p. 109), a recente explosão financeira esteve associada menos a um processo de desregulamentação do que a uma reconfiguração do arcabouço regulador, um "processo através do qual novas conexões organizacionais foram forjadas e relações particulares de controle institucional foram construídas e consolidadas" como afirma Harcourt (2012, p. 17), os mercados financeiros contemporâneos são constituídos por "camadas sobrepostas de supervisão governamental, de regras e regulações bursáteis, de supervisão federal e estadual" - além, é claro, de vários "mecanismos de autorregulação".

Em segundo lugar, as transformações institucionais que culminaram na autonomização do capital acionário não resultaram de um projeto consciente dos agentes envolvidos. Pelo contrário, como demonstra Krippner (2012, p. 58) em sua minuciosa análise dos eventos que levaram à reconfiguração institucional da esfera financeira nos EUA:

a criação do ambiente macroeconômico que conduziu à financeirização não foi um resultado deliberado buscado pelas formuladores de políticas públicas; pelo contrário, tratou-se de um resultado não planejado das tentativas desses formuladores de responder a uma constelação única de dificuldades que confrontaram o estado no final dos anos 1960 e na década de 1970.

(5) Ver também Panitch e Gindin (2013). 
Noutras palavras, as condições que impulsionaram o que chamamos de autonomização do capital acionário não resultaram de um plano consciente dos agentes envolvidos: na verdade, o processo de reconfiguração institucional que em boa medida desconectou os movimentos do capital acionário do processo efetivo de acumulação de capital emergiu de maneira não intencional das decisões e medidas por eles adotadas ${ }^{6}$. Ora, se é assim, então uma interpretação adequada do processo histórico de autonomização do capital acionário deve ser capaz de se desvencilhar do conteúdo consciente das ações através das quais tal processo se realizou; mais precisamente, ela deve superar a ideia de que o sentido desse processo deriva-se diretamente das intenções dos agentes envolvidos. E isso, como veremos, é algo que a abordagem marxiana ao problema da relação entre agência e estrutura está particularmente apta a fazer.

\section{Gênese e reprodução das formas sociais especificamente capitalistas}

Segundo Marx (2004, p. 327-328), na medida em que "se condicionam internamente", as formas sociais constitutivas do modo de produção capitalista formam "um todo orgânico", isto é, uma totalidade. Tal totalidade cabe notar, não possui um caráter atemporal; pelo contrário, ela é o produto de um processo histórico que a precede temporal e logicamente: "sua existência", afirma Marx (1974, p. 945), "é o resultado de um demorado processo histórico nas configurações econômicas da sociedade" 7 . E isso dá a ela um caráter paradoxal; pois, no momento em que a separação do trabalhador e da propriedade das suas condições de produção (Marx, 1983a, p. 262) se consolida, impondo sobre a atividade material humana os constrangimentos inerentes às leis de movimento do capital, as formas sociais necessárias ao bom funcionamento dessas mesmas leis não se encontram ainda plenamente desenvolvidas. Pelo contrário: "o devir totalidade [do capital] constitui um momento do seu processo, de seu desenvolvimento", e "seu desenvolvimento em direção à totalidade consiste precisamente em subordinar todos os elementos da sociedade ou criar para si os órgãos que ainda lhe faltam” (Marx, 2004, p. 203).

(6) Estudando especificamente a liberalização dos fluxos de capitais, Helleiner (1996, cap. 5 e 6) mostra que, se é verdade que tal processo esteve inicialmente relacionado à emergência das ideias neoliberais e de novos grupos de interesse dentro dos EUA, também é verdade que, já nos no final dos anos 1970, os formuladores de políticas pública tentaram, sem sucesso, estabelecer novos tipos de controle sobre os fluxos de capital, indicando assim que não se pode compreender a reconfiguração institucional em tela como mero resultado planejado das ações intencionais dos agentes envolvidos.

(7) "Que o possuidor de dinheiro encontre a força de trabalho no mercado, que o encontre nos limites da circulação como mercadoria: este pressuposto, da qual nós aqui partimos, e da qual a sociedade burguesa parte em seu processo de produção, obviamente o resultado de um longo desenvolvimento histórico, o resumé de muitos cataclismas (...) Este nível de desenvolvimento histórico da produção econômica - cujo produto mesmo é o trabalho livre -é, porém o pressuposto do devir e ainda mais da existência do capital enquanto tal. Sua existência é o resultado de um demorado processo histórico nas configurações econômicas da sociedade” (Marx, 1974, p. 945). 
Eis então que o modo de produção capitalista deve, em seu processo de desenvolvimento, não apenas reproduzir, mas também criar as formas sociais através das quais o capital se impõe como o "sujeito dominador [übergreifende]" (Marx, 1983b, p. 274) do processo de reprodução material da sociedade. Mas como poderia o próprio capital realizar tal tarefa, se "quem faz tudo é (...) o homem", isto é, "o homem real, que vive" (Marx; Engels, 2015) e luta? Como poderia o capital fazê-lo se, como o próprio Marx (2004, p. 371) enfatizou, toda relação de produção, e portanto, também o capital, é resultado da ação humana?

Para responder a essas perguntas, é necessário ter em mente que a totalidade configurada pelas relações constitutivas do modo de produção capitalista configura um sistema, ou seja, uma entidade caracterizada pela capacidade da autoorganização espontânea (Wolf, 2017), e que portanto a conexão entre ação individual e estrutura social possui, nas sociedades em que a troca se impõe como forma geral da relação material entre os indivíduos, um caráter bastante peculiar. Pois, à medida que os produtos do trabalho assumem a forma da mercadoria, a atividade produtiva deixa de se constituir imediatamente como um elo da divisão social do trabalho. Em tais condições, as relações e formas sociais que não são senão um resultado da atividade produtiva humana aparecem necessariamente para os indivíduos como algo que lhes é exterior, e portanto como um pressuposto de toda sua atividade (Heinrich, 2011, p. 207). Ora, na medida mesma em que se relacionam com tais relações não como resultado, mas como pressuposto de suas próprias ações, os indivíduos são levados a adequar estas últimas às leis objetivas que regem o funcionamento da totalidade de relações que eles mesmos criaram (Lukács, 2012). Eles "não o sabem, mas o fazem" (Marx, 1983b, p. 200): "[e]sta”, afirma Marx na primeira edição de $\mathbf{O}$ Capital, "é uma operação instintiva espontânea e portanto inconsciente de seu cérebro, que emerge necessariamente do modo peculiar de sua produção material e das relações nas quais essa produção os empenha" (Marx, 1867, p. 38). E, à medida que adequam suas ações imediatamente conscientes aos constrangimentos impostos pelas leis de movimento do capital, os indivíduos inconscientemente produzem e reproduzem a totalidade das relações e formas sociais necessárias ao transcorrer do "processo em que [o capital], por meio de uma mudança constante das formas (...) modifica sua própria grandeza, repele-se, como mais-valor, de si mesmo como valor original, se autovaloriza" (Marx, 1983b, p. 274). Noutras palavras, a sociabilidade capitalista conduz os indivíduos a inconscientemente criar e recriar, através das suas ações imediatamente conscientes, as formas sociais através das quais poderá se realizar o movimento de superação e reposição da contradição entre o impulso desmedido de autovalorização do valor e seu modo sempre limitado de existência imediata. 


\section{A necessidade estrutural do capital acionário}

É como resultante desse impulso imanente que se apresentam, no primeiro volume de $\mathbf{O}$ Capital, as tendências à concentração e à centralização do capital. Como se sabe, o capital só pode existir enquanto sujeito do metabolismo social ali onde os indivíduos se defrontam como pessoas (Marx, 1983b, cap. 2), isto é, onde uma reunião da riqueza social imediatamente enquato riqueza social é impossível; e no entanto, dirá Marx, o impulso à socialização da riqueza é-lhe imanente. $\mathrm{O}$ capital necessita portanto de um modo de se reunir consigo mesmo que não suprima sua oposição fundamental; noutras palavras, ele precisa de um mecanismo que permita a ele ser socializado enquanto propriedade privada. E isso, como veremos, é exatamente o que se vai encontrar nas formas do capital de empréstimo e do capital acionário.

Segundo Marx (1983a, p. 194), o processo de extração de mais-valor e acumulação de capital está intimamente associado ao crescimento da produtividade social do trabalho: "[t]odos os métodos de elevar a força produtiva social do trabalho" são, afinal, no modo de produção capitalista, "ao mesmo tempo, métodos de elevar a produção de mais-valor ou mais-produto, que, por sua vez, é o elemento constitutivo da acumulação" (ibidem, p. 195-196). O nível da produtividade do trabalho, por seu turno, é determinado em boa medida pelo "volume relativo dos meios de produção que um trabalhador, durante um tempo dado, com o mesmo dispêndio de força de trabalho, transforma em produto": a "massa dos meios de produção", afirma Marx, "cresce com a produtividade [do] trabalho" (idem, ibidem). E é por isso que geralmente encontramos, nas sociedades em que predomina o modo de produção capitalista, uma tendência à elevação da razão trabalho morto/trabalho vivo.

Note-se, todavia que, de uma perspectiva estritamente capitalista, a elevação dessa relação não possui qualquer significado direto: ao capital, a medida física (massa) pela qual essa variação foi acima considerada só importa caso se exprima também na dimensão dos valores. Como, porém “o crescimento da massa dos meios de produção, comparada à massa da força de trabalho que os vivifica, reflete-se em sua composição em valor, no acréscimo da componente constante do valor do capital à custa de sua componente variável" (ibidem, p. 194), pode-se dizer que existe, nas sociedades em que predomina o modo de produção capitalista, uma tendência à elevação da composição-valor do capital.

É importante enfatizar aqui que, não obstante sua enorme importância, a elevação da composição técnica do capital não constitui a única alavanca da produtividade. Pelo contrário, um outro fator concorre para esse mesmo fim: a cooperação entre os produtores diretos. Ora, como se sabe, a produção capitalista existe somente onde o processo produtivo se organiza sob o signo da propriedade 
privada; e se, como afirma Marx (1983a, p. 195), “o terreno da produção de mercadorias só pode sustentar [tragen] a produção em larga escala na forma capitalista", então aqui a cooperação a princípio só pode crescer através do crescimento dos capitais individuais.

Sobre a base da produção de mercadorias, na qual os meios de produção são propriedade de pessoas privadas, em que o trabalhador manual produz mercadorias, portanto de modo isolado e autônomo ou vende sua força de trabalho como mercadoria porque lhe faltam os meios para produzir autonomamente, [o crescimento da cooperação - $\mathrm{BH}$ ] só se realiza pelo crescimento dos capitais individuais (ibidem, p. 195).

Tal crescimento, cabe notar, é impulsionado pela própria luta da concorrência, a qual tende a promover a absorção dos capitais menores pelos maiores. Como afirma Marx (idem, p. 196): "toda acumulação torna-se meio de nova acumulação. Ela amplia, com a massa multiplicada da riqueza, que funciona como capital, sua concentração nas mãos de capitalistas individuais e, portanto, a base da produção em larga escala e dos métodos de produção especificamente capitalistas". Assim, "o crescimento do capital social se realiza no crescimento de muitos capitais individuais. Pressupondo-se as demais circunstâncias constantes, os capitais individuais crescem e, com eles, a concentração dos meios de produção, na proporção em que constituem partes alíquotas do capital global da sociedade" (ibidem, p. 196).

Podemos, então, imaginar uma situação em que o capital social venha, através da reiterada vitória na luta concorrencial do maior capital sobre os menores, a apresentar-se como um único capital particular - estado limítrofe que de fato se realizaria, caso permanecessem constantes as demais circunstâncias. As circunstâncias, contudo, variam; pois, não obstante a tendência do capitalista a idealmente eternizar seu capital, ele mesmo é, em sua individualidade, mortal. Daí que sua riqueza individual só possa sobreviver como capital (i.e, na forma da propriedade privada) nas mãos de herdeiros - os quais, em muitos casos, soem ser mais de um. Desse modo, ao mesmo tempo que se concentra a riqueza na forma do capital individual, outras "parcelas se destacam dos capitais originais e passam a funcionar como novos capitais autônomos" (Marx, 1983a, p. 196).

O capital se encontra, portanto, em autocontradição. Segundo suas próprias determinações ele deve reunir-se consigo mesmo, concentrar-se; mas ele também deve respeitar sua determinação como propriedade privada, determinação que constitui sua própria condição de possibilidade - e que, no entanto, apresenta-se imediatamente como uma barreira à realização do impulso que acabamos de apresentar. Na forma da propriedade privada dos meios de produção, portanto, o capital é uma contradição imediata - e esta, como tende a acontecer com as contradições do capital, precisa se desenvolver. Daí que, a "essa dispersão do capital 
global da sociedade em muitos capitais individuais ou a repulsão recíproca entre suas frações" (ibidem, p. 196), oponha-se um outro impulso - o da sua atração:

É a concentração de capitais já constituídos, supressão de sua autonomia individual, expropriação de capitalista por capitalista, transformação de muitos capitais menores em capitais maiores. Esse processo se distingue do primeiro porque pressupõe apenas divisão alterada dos capitais já existentes e em funcionamento, seu campo de ação não estando, portanto, limitado pelo crescimento absoluto da riqueza social ou pelos limites absolutos da acumulação. (...) É a centralização propriamente dita, distinguindo-se da acumulação e da concentração. (Ibidem, p. 196)

Há, pois, um outro modo de concentração do capital, o qual não apenas se contrapõe àquele primeiro, idêntico à acumulação, mas também supera seus limites: a centralização. Tal processo "não depende, de nenhum modo, do crescimento positivo da grandeza do capital social"; pelo contrário, ele "pode ocorrer por meio da mera mudança da distribuição de capitais já existentes, mediante mudança simples do agrupamento quantitativo dos componentes do capital social" (Ibidem, p. 197).

Note-se porém que, na forma de centralização apresentada, isto é, a da absorção de alguns capitais individuais por parte de outros capitalistas via concorrência, o capital permanece propriedade da pessoa física, com o que ainda não é capaz de superar completamente a contradição apresentada acima. Com efeito, o processo de centralização, restrito a essa forma, não se realiza muito mais rapidamente do que a mera concentração imediata. De modo muito mais veloz ocorrerá, por outro lado, caso os vários capitais consigam reunir-se qua capitais individuais. E é por isso que:

[C]om a produção capitalista constitui-se uma potência inteiramente nova, o sistema de crédito, que, em seus primórdios, se insinua furtivamente como modesto auxiliar da acumulação, levando por fios invisíveis recursos monetários, dispersos em massas maiores ou menores pela superfície da sociedade, às mãos de capitalistas individuais ou associados, mas logo se torna uma nova e temível arma na luta da concorrência e finalmente se transforma em enorme mecanismo social para a centralização dos capitais (Ibidem, p. 196197).

Assim, "à medida que se desenvolve a produção e acumulação capitalista, na mesma medida desenvolvem-se concorrência e crédito" (Ibidem, p. 197). Pois, soldando entre si "as massas de capital (...) da noite para o dia", o crédito permitelhes reproduzir-se e multiplicar-se "mais rapidamente e, com isso, [as transforma em - BH] novas e poderosas alavancas da acumulação social” (ibidem, p. 198).

No crédito, portanto, o capital encontra uma forma na qual supera a contradição acima exposta. Mas que fique claro: falamos aqui do capital a crédito 
em geral, e não apenas na forma ordinária do empréstimo de capital. Pois também na sociedade por ações - "a mais perfeita forma” (Marx, 1970, p. 312) do capital encontraremos uma forma na qual na qual a riqueza privada poderá se socializar sob as condições impostas pela propriedade privada, levando o processo de centralização, "num piscar de olhos”, à sua máxima dimensão (Marx, 1983a, p. 198).

Capital de empréstimo e capital acionário: eis aqui duas formas através das quais o capital pode reunir-se mediatamente consigo mesmo; duas formas, portanto, que se desenvolvem a partir da mesma contradição. Não à toa, ambas serão apresentadas por Marx como formas particulares de uma mesma entidade: o capital portador de juros. E assim nos aproximamos da razão que impediu Marx de desenvolver essas duas formas no primeiro volume de O Capital - e isso apesar de, como vimos, já ter demonstrado a necessidade dessas duas formas nesse estágio da exposição conceitual. É que no primeiro volume da principal obra de Marx ainda nos encontramos em altíssimo nível de abstração: o nível do capital em geral (Marx, 1970, p. 312), estágio da exposição no qual o teórico, municiado por sua análise minuciosa, expõe de modo imediato as leis de movimento do capital, sem ainda atentar para o modo como tais leis se impõem sobre a realidade. Evidentemente, tais leis só podem se impor sobre a reprodução material da sociedade através das relações imediatas entre os diversos capitais individuais. E a conexão entre tais leis e a interação aparentemente caótica dos capitais particulares é o objeto do terceiro volume da principal obra de Marx, onde se trata "de encontrar e expor as formas concretas que emergem do processo de movimento do capital, considerado como um todo" (Marx, 1985, p. 23, grifo do autor).

Ora, a categoria do juro diz respeito precisamente à dimensão dos capitais particulares. Com efeito, a forma do capital portador de juros surge de um processo de inversão no qual o capital particular se reconhece, enquanto capital particular, como sujeito; ela só pode, por conseguinte, ser derivada no último tomo de $\mathbf{O}$ Capital. Esclarece-se assim por que Marx não desenvolveu a forma do capital acionário ali mesmo onde demonstrara sua necessidade; e descobre-se, simultaneamente, o motivo que levará nosso desenvolvimento conceitual a dar um salto expositivo e cair diretamente na antepenúltima seção da principal obra de Marx, onde encontraremos a exposição da categoria que pretendemos examinar agora: a do capital portador de juros.

\section{O capital portador de juros}

"Dinheiro - considerado aqui como expressão autônoma de uma soma de valor, exista ela de fato em dinheiro ou em mercadorias - pode, sobre a base da produção capitalista, ser transformado em capital, e passa, em virtude dessa transformação, de um valor dado para um valor que se valoriza a si mesmo, que se 
aumenta. Produz lucro, isto é, capacita o capitalista a extrair dos trabalhadores determinado quantum de trabalho não pago, mais-produto e mais-valia, e apropriarse dele" (Marx, 1985, p. 255). Em função dessa sua capacidade - a qual ele deve à existência, no mercado de trabalho, da mercadoria cujo uso produz valor e maisvalor - a expressão autônoma do valor adquire, enquanto valor, um valor de uso. Ela "[a]dquire, além do valor de uso que possui como dinheiro, um valor de uso adicional, a saber, o de funcionar como capital. Seu valor de uso consiste aqui justamente no lucro que, uma vez transformado em capital, produz. Nessa qualidade [Eigenschaft] de capital possível, de meio de produção de lucro, torna-se mercadoria, mas uma mercadoria sui generis. Ou, o que dá no mesmo, o capital enquanto capital se torna mercadoria" (ibidem, p. 255): mercadoria-capital.

Essa mercadoria peculiar não ingressa na arena econômica da mesma forma que as demais. Estas vale lembrar, são compradas e vendidas; em suas trocas invertem-se, portanto, seus proprietários - os quais cedem o valor de uso da mercadoria que detinham, mas não seu valor. Evidentemente, o mesmo não poderia ser feito com uma mercadoria que é cedida como capital. Pois, como já vimos, seu valor de uso é justamente o de ser valor e, em conseqüência disso, "poder ser transformado em capital, (...) poder funcionar como capital e assim produzir em seu movimento determinado mais-valor" (ibidem, p. 264). Logo, seu proprietário simplesmente não pode ceder seu valor de uso sem ceder seu valor. Pelo contrário, ele deve entregar sua mercadoria numa transação distinta da troca ordinária: uma na qual ele não recebe qualquer valor em troca daquele que cede.

Tal transação, é claro, seria absurda caso fosse encerrada neste ponto. Com efeito, nosso capitalista só cede sua mercadoria a outrem com a condição de recebêla de volta após determinado prazo - e não mais sozinha, mas acompanhada de filhotes. Reclama seus direitos, embasado nas propriedades da mercadoria que cedera, a qual "tem a peculiaridade de que, pelo consumo de seu valor de uso, seu valor e seu valor de uso não só são conservados, mas multiplicados” (Marx, 1985, p. 264); lembra assim ao mutuário que não lha vendera, mas a emprestara.

"A forma do empréstimo", diz Marx, "resulta já da determinação de que o capital se encontra aqui como mercadoria ou de que o dinheiro como capital tornase mercadoria" (ibidem, p. 257). Atentemos para a singularidade dessa forma. Sabese que a exposição conceitual empreendida por Marx em O Capital consiste na dedução das relações e formas sociais concretas constitutivas do modo de produção capitalista a partir de sua relação mais geral: a da troca. Cabe notar, porém, que embora a relação de empréstimo seja legitimada por um acordo entre a vontades de indivíduos juridicamente livres, nela nada é trocado. De fato, o que encontramos na relação de empréstimo é a forma da troca, sem o seu contéudo. E isso significa que, diferentemente do que ocorre com o movimento de outras mercadorias, o movimento da mercadoria-capital "não expressa ato algum da metamorfose [do valor $-\mathrm{BH}$ ], 
nem compra nem venda" (ibidem, p. 261). Noutras palavras, a relação que as partes mantêm entre si não é de caráter econômico, mas sim jurídico.

Note-se, contudo, que a mercadoria é aqui emprestada como capital; e, para que como tal se realize, ela deve se infiltrar no processo econômico e gerar um valor excedente. Daí que, se quisermos entender a relação do capital portador de juros com o processo de reprodução global do capital, não poderemos nos restringir à relação mantida por mutuário e prestamista. Pelo contrário, teremos que abandonar este e acompanhar aquele, a quem caberá decidir se a soma de valor emprestada como capital será efetivamente empregada como tal. Sabendo que a tomou emprestada como capital, sabe também que deve devolvê-la como tal; e, temendo as conseqüências com que arcará caso não cumpra seu contrato, tende a pô-la rapidamente a gerar os filhotes que prometia.

Tais filhotes, o dinheiro só os possuía idealmente; é necessário, portanto, ir retirá-los à sua verdadeira fonte. E o capitalista funcionante o faz passando da esfera da circulação à da produção, e voltando depois ao mercado para realizar monetariamente os frutos colhidos. Executa, assim, o movimento que caracteriza o metabolismo econômico capitalista:

\section{D-M-D'}

O capitalista funcionante pode agora cumprir o contrato previamente assinado não apenas sem ter que se desfazer de seus bens, mas adicionando a eles algo mais - cuja magnitude, por seu turno, depende tanto do valor que consegue resgatar ao final do movimento descrito acima quanto do juro que acordara pagar no início do processo. Nós, por outro lado, podemos visualizar o movimento completo realizado pelo valor através das ações de mutuário e prestamista:

\section{D-D-M-D'-D'}

Examinemos essa expressão. Já à primeira vista se nota: o excedente do qual se apropria o primeiro capitalista só existe porque o capital funcionou como capital. Mas, se a soma de valor só se pode realizar como capital nas mãos do capitalista funcionante, este, por outro lado, pôde fazê-la funcionar como capital apenas porque ela lhe foi adiantada como tal. Depende pois, de uma transação jurídica que a soma de valor possa se realizar como capital; e de transações econômicas dependerá que ela efetivamente se realize como tal. Assim, embora se trate aqui sempre de uma única soma de valor, esta mesma é aqui despendida duas vezes como capital. Por conseguinte, ela também precisa refluir duas vezes como tal:

[A] primeira mudança de posição do dinheiro não constitui momento algum (...) da reprodução do capital. Isso ele só se torna no segundo dispêndio, nas mãos do capitalista funcionante, que com ele comercia ou o transforma em capital produtivo. (...) A esse duplo dispêndio do dinheiro como capital (...) 
corresponde seu duplo refluxo. Como D' (...) reflui do movimento ao capitalista funcionante (...) Este o transfere então para [o prestamista - BH], mas ao mesmo tempo com uma parte do lucro, como capital realizado (Marx, 1985, p. 257).

Ora, se por um lado dispêndio e refluxo ocorrem duplamente no movimento completo da mercadoria-capital, seu movimento enquanto mercadoria-capital, por outro, aparece como "mero resultado de uma transação jurídica entre o proprietário do capital e uma segunda pessoa" (Marx, 1985, p. 263). Aqui, portanto, "vemos somente entrega e reebolso. Tudo o que ocorre de permeio é apagado" (Marx, 1985, p. 263). Se sabemos que a valorização do capital se dá exclusivamente entre a concessão da mercadoria-dinheiro e seu refluxo ampliado às mãos de seu proprietário, é porque antes deixáramos o verdadeiro proprietário da mercadoriadinheiro e acompanháramos o mutuário em sua peregrinação pela circulação e pela produção. O prestamista, todavia, seguiu seu rumo e reencontrou o capitalista funcionante somente quando este não mais cumpria tal papel - reencontrou-o, portanto, como simples mutuário. Para ambos, sua relação se reduz à transação jurídica que os liga, a qual se exprime economicamente no seguinte movimento:

$$
\text { D-D' }
$$

A mesma soma de valor aparece simultaneamente como o capital em duas formas diferentes de existência: "como capital emprestável nas mãos do prestamista, como capital industrial ou comercial nas mãos do capitalista funcionante" (Marx, 1985, p. 273). Nada mais natural então do que aparecer ela também duplicada na representação dos agentes enredados por esse movimento. Pois, embora o capital se encontre não apenas sob o controle do mutuário, mas mesmo indisponível - pois imobilizado - enquanto produz e circula, o prestamista, "que nunca deixou de ser seu proprietário jurídico" (ibidem, p. 267), tem sempre consigo um título que lhe permite, a qualquer momento, obter uma soma de dinheiro nos mercados secundários. Assim, o mero ato do empréstimo faz com que uma dada soma de valor se duplique na representação dos agentes, existindo não mais exclusivamente em seu circuito efetivo, mas também de modo ideal num título que a representa, um capital fictício, cujo preço segue leis completamente distintas das que regulam o valor efetivamente empregado no processo de reprodução ampliada. Para os contratantes, tudo se passa como se o mesmo capital existisse simultaneamente em duas entidades distintas: capital como propriedade e capital como função.

Ora, se o capital aparece duplamente representado, o excedente também terá que aparecer em duas representações distintas. Dito de outra maneira: o mais-valor produzido terá que se dividir em duas rubricas, apresentando-se, por um lado, como excedente que remunera o capital como propriedade e, por outro, como excedente que remunera o capital em seu funcionamento como capital. Ainda mais: como o fato de que o dinheiro com o qual se iniciou a produção era emprestado em nada 
altera o valor do produto, tais rubricas não podem consistir senão em partes do maisvalor total, as quais serão divididas entre pessoas (no sentido jurídico do termo) distintas: numa, chamada juro, se exprime a remuneração do capital enquanto propriedade; noutra, o ganho do empresário, representa-se sua remuneração enquanto função.

Examinemos a primeira rubrica, remuneradora do capital enquanto propriedade. É importante que se tenha em mente, desde o início, a distinção conceitual entre taxa de juros como grandeza empírica e taxa de juros como uma média temporal. No que se refere a esta última, é evidente que, sendo o juro nada mais do que uma parte do mais-valor gerado pelo capital em seu movimento, seus limites aritméticos estão sempre dados por este mesmo valor excedente, ou melhor, pela taxa média de mais-valor. Isso não significa, porém, que a taxa média de juro possa ser matematicamente derivada dessa última. Pelo contrário: como afirma Marx (ibidem, p. 273), “[a] maneira como duas pessoas que têm direito a [certa parte do $\mathrm{BH}$ ] lucro o dividem é em si e para si um fato puramente empírico, pertencente ao reino do contingente [des Zufälligen]". Noutras palavras, longe de determinar plenamente a taxa média de juro, a taxa de mais valor apenas indica os limites dentro das quais ela pode se mover: embora não seja senão uma parte do mais-valor, o juro médio não é, enquanto grandeza, totalmente determinado pelo mais-valor - do que se deduz que o conceito de taxa natural de juro é nada mais do que um contrassenso.

Cabe notar, porém, que o grau de autonomia do juro em relação ao maisvalor do qual ele se origina é ainda maior quando o que se tem em vista é não a taxa média, mas a taxa imediata de juro. E isso não apenas porque essa taxa, enquanto preço da mercadoria-capital, é determinada imediatamente pela relação entre a oferta e a demanda da mercadoria em questão, mas sobretudo porque tal preço é estabelecido contratualmente entre prestamista e mutuário antes que a soma de valor emprestada seja efetivamente transformada em capital. Daí que o juro possa ser, em certos setores e por períodos limitados, igual, ou mesmo maior do que o mais-valor total - situação na qual os capitalistas funcionantes são obrigados a transferir parte de seu estoque de riqueza aos proprietários do capital que tomaram emprestado.

Essa, contudo, não é a única peculiaridade da taxa de juro. Com efeito, na medida em que aparece como o preço da mercadoria-capital, e portanto como uma magnitude determinada antes da transformação efetiva do valor emprestado em capital, o juro se põe também como a única parte do mais-valor que aparece, a cada momento, como uma grandeza dada, fixa - e fixada do mesmo modo para toda e qualquer mercadoria-capital disponível no mercado. Noutras palavras, o juro é uma forma assumida pelo excedente que é quantitativamente igual para todos os capitais: "[n]o que tange à taxa de mercado sempre flutuante de juros", afirma Marx (1985, p. 274), "ela em cada momento é dada como grandeza fixa, como o preço de mercado das mercadorias, pois no mercado de dinheiro todo o capital emprestável sempre se 
defronta como massa global ao capital funcionante, de modo que a relação entre a oferta de capital emprestável, de um lado, e a procura por ele, por outro, decide o nível de mercado do juro em cada momento" - característica que se acentua com o desenvolvimento do sistema de crédito. Existe então no mercado uma taxa geral de juro, uma taxa que varia no tempo, mas que é, em cada momento, idêntica para todo e qualquer capital emprestável.

Isso distingue fortemente a forma do juro da forma do lucro. Pois a taxa geral de lucro, ao contrário da taxa de juro, nunca existe como grandeza dada, mas apenas como tendência, i.e. como:

Movimento de equalização das taxas particulares de lucro (...) As taxas particulares de lucro nas diversas esferas da produção são, elas mesmas, mais ou menos incertas; mas, na medida em que aparecem, não é sua uniformidade, mas sua diversidade que aparece. A taxa geral de lucro, entretanto, aparece apenas como limite mínimo do lucro, e não como figura empírica, diretamente visível da taxa de lucro efetiva (Ibidem, p. 274-275).

Vemos então que, como grandeza imediata, o juro é, a cada momento: i) idêntico para todo valor-capital emprestável; e ii) definido contratualmente antes da realização do valor emprestado como capital. Assim, embora o modo de refluxo efetivo do capital adiantado seja determinado pelo circuito do capital no processo de acumulação - dependendo, portanto, dos modos particulares que esse movimento assume - para o capital emprestado, o refluxo assume a forma de um mero desembolso, porque a alienação assumira a forma do empréstimo. É portanto imanente ao movimento da mercadoria-capital que o juro apareça como uma grandeza autônoma frente ao mais-valor, algo que cabe ao capital enquanto propriedade, seja ele posto em movimento ou não. $\mathrm{O}$ juro se apresenta então como algo que o valor gera por si mesmo, seu fruto natural:

Tão logo esteja emprestado ou também investido no processo de reprodução (desde que proporcione ao capitalista funcionante, como seu proprietário, juros separadamente do ganho empresarial), acresce-lhe o juro, esteja dormindo ou acordado, em casa ou em viagem, de dia ou de noite (Marx, 1985, p. 295).

Para seu proprietário, a grandeza de valor cedida a outrem como capital constitui capital única e exclusivamente porque fora emprestada como tal - ato jurídico que por si mesmo garante a ele a apropriação de um valor excedente sob a forma do juro. Por conseguinte, o juro - que não é mais do que a expressão objetiva do fato de que toda soma de valor, nas sociedades em que a mercadoria cujo uso produz valor e mais-valor está sempre disponível no mercado de trabalho, é potencialmente capital - aparece como uma forma de rendimento que toda soma de valor é capaz de produzir por si mesma. Através de um processo de inversão imanente ao modo de produção capitalista, o valor - que só se transforma efetivamente em capital na medida em que se submete ao processo de valorização - 
se apresenta, em sua existência imediata, como capital. O juro aparece então como aquilo que se paga pela valorização que por si mesmo este último gera - e, por conseguinte, como algo que cabe ao possuidor de dinheiro não porque este dinheiro é utilizado na exploração da força de trabalho, mas simplesmente porque o possui. O capital agora porta, em si mesmo, o juro: é capital portador de juros ${ }^{8}$.

Eis então que, na forma do capital portador de juros, o capital parece se autonomizar em relação às determinações materiais do seu processo de reprodução. Com efeito, em nenhuma das demais formas imanentes ao processo de reprodução ampliada o capital aparece imediatamente como capital. Como nota Marx (1985, p. 258), na forma do capital-dinheiro, ele atua "apenas como dinheiro"; e, na forma do capital-mercadoria, "apenas como mercadoria". Em ambos os casos, portanto, as formas particulares assumidas pelo capital aparecem não como capital em si, mas como o que de fato são: meros momentos do processo de reprodução ampliada. "É só na conexão de todo o circuito (...) em D-D' ou M-M', que o capital se apresenta no processo de circulação como capital" (ibidem, p. 258).

Adiantado como mercadoria-capital, porém, o dinheiro (figura autonomizada do valor) não mais aparece como momento do processo de reprodução ampliada do capital; pelo contrário, ele "encarna em si o próprio movimento" (Paulani, 1992, p. 155), "é o capital acabado, unidade do processo de produção e do processo de circulação, e que, portanto proporciona determinado mais-valor em determinado período de tempo" (Marx, 1985, p. 293). Aqui, conclui Marx, o objeto de valor aparece "como fonte misteriosa, autocriadora do juro, de seu próprio incremento", i.e. como algo que naturalmente constitui capital:

A coisa (dinheiro, mercadoria, valor) já é capital como mera coisa; o resultado
do processo global de reprodução aparece como propriedade que cabe por si a
uma coisa (...) No capital portador de juros, portanto, esse fetiche automático
está elaborado em sua pureza, o valor que valoriza a si mesmo (...) e ele não
mais porta nesta forma marca alguma de seu nascimento. A relação social está
consumada como relação de uma coisa (...) consigo mesm[a]. Em vez da
transformação efetiva do dinheiro em capital aqui se mostra apenas sua forma
sem conteúdo (...) Torna-se assim propriedade do dinheiro criar valor,
proporcionar juros, assim como a de uma pereira é dar pêras. E como tal coisa
portadora de juros vende o prestamista seu dinheiro. (...) Em D-D', temos a
forma sem-conceito [begriffslose] do capital, a inversão e coisificação das
relações de produção em sua potência mais elevada (...) a capacidade do
dinheiro, respectivamente da mercadoria, de valorizar seu próprio valor,

(8) Ressalte-se que essa inversão não se deriva da irracionalidade dos agentes envolvidos. Pelo contrário, ela exprime de maneira unilateral as determinações objetivas da sociabilidade capitalista. Pois não apenas o proprietário do capital de fato recebe os juros que lhe cabem, seja seu dinheiro empregado na produção de maisvalia ou não, mas a própria magnitude desses juros, como já vimos, é realmente determinada não na produção, mas contratualmente, refletindo a casual relação entre oferta e demanda. 
independentemente da reprodução - a mistificação do capital em sua forma mais crua (Marx, 1985, p. 293-294).

\section{O capital acionário}

Para poder constituir capital, a riqueza material deve se encontrar sob a forma da propriedade privada. Já vimos porém, que o próprio processo de acumulação dá origem a um impulso à socialização da riqueza material. Noutras palavras, o capital se encontra, na forma da simples propriedade privada, em contradição consigo mesmo. Tal contradição, no entanto, será resolvida na forma do capital portador de juros. Oferecendo-se como mercadoria, o capital pode se socializar sem suprimir seu caráter de propriedade privada. Através de sua duplicação ideal, ele cinde e exterioriza suas determinações, aparecendo simultaneamente como propriedade e como função em dois entes distintos. E com isso consegue, a um só tempo, suprimir e conservar a contradição que o atormenta.

Não é contudo, na forma ordinária do empréstimo de capital que isso pode acontecer. Nesta, como se sabe, a soma de valor, enquanto principal, deve necessariamente voltar às mãos de seu proprietário. Assim, se a pessoa (seja ela física ou jurídica), enquanto tomadora de empréstimo, pode idealmente reunir todo o capital disponível na economia, ela por outro lado deve periodicamente devolvê-lo a seus proprietários efetivos: na sua reunião, o capital sempre acaba, sob essa forma, por repelir-se novamente.

Tal resultado não é casual. Não sendo plenamente cedida, a mercadoriacapital deve reiteradamente suprimir sua duplicidade. Com efeito, uma vez quitada a dívida, desaparece a dupla representação do capital: parte-se de sua cisão, mas volta-se sempre à sua unidade imediata. Se propriedade e função aparecem cindidas durante o circuito do capital de empréstimo ordinário, elas o fazem apenas para novamente se reunirem na linha de chegada. Não se completando a exteriorização de suas determinações, não pode o capital reunir-se plenamente consigo mesmo senão de modo imediato (e, portanto, como já foi visto, insuficiente): como sempre sói acontecer a este ser contraditório, não sendo plena a oposição, plena não será a unidade - uma verdade que se exprime cotidianamente nos limites que o endividamento impõe à captação de recursos pelas companhias privadas.

Do ponto de vista expositivo, as consequências disso são inequívocas. Por mais desenvolvido que apareça o capital na figura do capital de empréstimo, essa não pode ainda constituir "sua última forma" (Marx, 2004, p. 436). A “oposição entre o caráter social da riqueza e a riqueza privada" deve portanto, se desenvolver "numa nova figura" (Marx, 1985, p. 334), uma forma na qual a duplicação ideal do capital e sua cisão em capital como propriedade e capital como função seja levada a seus limites máximos, com o que se chegará à "superação [Aufhebung] da propriedade privada dentro de suas próprias condições". E isso é justamente o que 
encontraremos na última forma do capital portador de juros, a "mais perfeita das formas" do capital: o capital acionário, sobre o qual se erege a sociedade por ações moderna.

O capital, que em si repousa sobre um modo social de produção e pressupõe uma concentração de meios de produção e forças de trabalho, recebe aqui diretamente a forma de capital social (capital de indivíduos diretamente associados) em oposição ao capital privado, e suas empresas se apresentam como empresas sociais em oposição às empresas privadas. É a superação [Aufhebung] do capital como propriedade privada, dentro dos limites do próprio modo de produção capitalista (Ibidem, p. 332)

Chegamos assim aos limites da propriedade privada, ou seja, a um modo de organização no qual os capitalistas podem, através da criação de uma nova pessoa jurídica, reunir seus capitais sem abrir mão de sua própria personalidade (no sentido jurídico do termo). De fato, eles aqui se unem como proprietários privados, ou seja, como indivíduos cuja responsabilidade jurídica se limita às somas de valor adiantadas como capital por cada um deles, numa transação que mantém a forma da troca mas, em hipótese alguma, seu conteúdo.

Da "superação da propriedade privada" dentro dos seus próprios limites resultarão finalmente as tão almejadas cisão e exteriorização completas das determinações da mercadoria-capital. Pois aqui se tem a:

Transformação do capitalista efetivamente [wirklich] funcionante em mero dirigente, administrador de capital alheio, e dos proprietários de capital em meros proprietários, simples capitalistas monetários. (...) Nas sociedades por ações, a função é separada da propriedade de capital, portanto também o trabalho está separado por completo da propriedade dos meios de produção e do mais-trabalho (ibidem, p. 332).

O corolário é óbvio: uma vez que se tenham separado propriedade e função, também o valor-capital deverá se refletir necessária e permanentemente numa segunda forma, um título, um capital fictício cujo preço é determinado não pelo valor outrora adiantado e agora empregado nas operações de valorização, mas sim pelo rendimento futuro que, espera-se, tal título proporcionará a seu proprietário. No capital acionário, portanto, o valor-capital se encontra plenamente duplicado: existe efetivamente no capital imobilizado no processo de produção e circulação de mercadorias, e idealmente no capital acionário.

Os títulos em que se materializa essa forma do capital são negociáveis a qualquer momento nas bolsas de valores. Todos devem então, como consequência das leis naturais da concorrência, ser capazes de gerar o mesmo rendimento (descontadas as diferenças de risco). Daí que as ações, como os títulos de dívida acima examinados, sejam sempre qualitativamente indiferentes umas às outras - ou, 
dir-se-ia melhor: idênticas em qualidade a todos os títulos que garantem a seu proprietário a apropriação de parte do valor excedente produzido no futuro. Evidencia-se, assim, que o dividendo é, no que se refere a suas determinações fundamentais, nada mais do que uma forma de juro.

[O] lucro total passa a ser recebido somente na forma de juro, isto é, como mera recompensa à propriedade do capital. O lucro se apresenta assim (e não mais apenas uma parte do mesmo, o juro, que extrai sua justificação do lucro do mutuário) como simples apropriação de mais-trabalho alheio, oriundo da transformação dos meios de produção em capital, isto é, de seu estranhamento [Entfremdung] em face dos produtores reais, de sua oposição como propriedade alheia a todos os indivíduos realmente ativos na produção (Marx, 1985, p. 332).

Como parte do lucro, o dividendo (assim como o juro) encontra na magnitude daquele o seu limite superior. Termina aí, contudo, a determinação do dividendo pelo lucro; pois, como também foi visto acima, é da natureza do rendimento que cabe ao capital enquanto propriedade não ser uma função prédefinida do mais-valor, do que se infere que o rendimento que assume a forma do dividendo pode, em certos momentos, ser maior do que o próprio excedente.

Não estaríamos, numa tal situação, diante de absurdo algum. Afinal, na própria medida em que se apresenta como uma forma do juro, o dividendo aparece também como algo que deve caber ao capital em decorrência de sua mera existência como coisa de valor. E, por mais irracional que pareça tal representação, ela é, para cada agente individual, absolutamente verdadeira. Pois, enquanto títulos imediatamente negociáveis nos mercados secundários, as ações podem ser transformadas a qualquer momento numa soma de valor sob a forma do dinheiro. Esta última, como sabemos, terá o valor de uso de funcionar como capital, ou seja, aparecerá como algo em si mesmo capaz de gerar um excedente na forma do juro. E isso significa que, ao exigir seus dividendos, o acionista apenas reivindica aquilo que seu capital é, por si mesmo, capaz de gerar: longe se comportar injustamente, ele apenas exige o cumprimento daquilo que se lhe aparece como uma lei natural.

\section{O processo histórico de autonomização do capital acionário}

Vimos acima que o capital acionário, forma autonomizada do capital que dá a seu proprietário o direito de receber parte dos rendimentos futuros de uma empresa, e cujo preço não guarda qualquer relação imediata com o valor do capital efetivamente investido na extração desses rendimentos, é uma forma social imanente ao modo de produção capitalista. Daí não se segue, todavia, que tal forma tenha existido desde os primórdios desse modo de produção. Pelo contrário, embora formas antediluvianas do capital acionário possam ser encontradas na antiguidade romana (Smith, 2003, p. 10-11), nas repúblicas italianas (Kindleberger, 1993, p. 190- 
191), nas feiras de Bruges - onde, no século XVI, o termo bolsa assumiu o sentido que hoje damos a ele (Smith, 2003, p. 15) - e nas grandes companhias de comércio do século XVII (Baskin; Miranti Jr., 1999, cap. 2), em nenhum desses casos o capital acionário havia se colocado efetivamente como entidade distinta do capital empregado na atividade econômica enquanto tal.

Com efeito, do ponto de vista jurídico, tal separação se desenvolveu nos principais países capitalistas apenas em meados do século XIX, quando novas leis instituíram a responsabilidade limitada do acionista, estabelecendo assim uma importante distinção entre a personalidade jurídica do acionista e a da firma (Kindleberger, 1993, cap. 11). Isso cabe notar, não se deu em função das preferências pessoais ou dos interesses dos agentes envolvidos no processo. Pelo contrário, a instituição da responsabilidade limitada era impopular não apenas entre os membros das classes mais abastadas - que viam em tal mecanismo algo contrário a seus interesses (ibidem, p. 196) -, mas também entre os economistas e o público em geral, para quem "a responsabilidade limitada (...) encorajaria acionistas e administradores a incorrer em riscos irresponsáveis" (Smith, 2003, p. 54). Assim, se a incorporação com responsabilidade limitada se disseminou aceleradamente a partir dos anos 1850 , foi porque as pressões objetivas em favor da centralização do capital se tornaram irresistíveis: como afirma Kindleberger (1993, p. 202), a instituição do princípio da responsabilidade limitada deveu-se sobretudo ao fato de que a quantidade de capital da qual necessitavam os novos empreendimentos capitalistas ("ferrovias, minas, companhias marítimas, bancos e um número crescente de empreendimentos industriais") não poderia ser suprida num contexto em que a distinção legal entre a personalidade da empresa e a do acionista não fosse respeitada.

Note-se porém, que embora constitua uma condição necessária, a responsabilidade limitada está longe de constituir a condição suficiente para o pleno desenvolvimento do capital acionário enquanto forma autonomizada do capital. Com efeito, do ponto de vista econômico, a autonomização do capital acionário só se concluirá na segunda metade do século XX, ao cabo de um processo que pode ser dividido em duas etapas. A primeira, iniciada ainda no século XIX, consistiu no abandono progressivo dos métodos de precificação de ações baseados diretamente no valor dos ativos empregados no processo de extração de mais-valor e na adoção de métodos em que os lucros ou dividendos historicamente observados cumprem papel crucial no cálculo do preço correto das ações (Rutterford, 2004). Na medida em que ancora os preços das ações não mais no valor dos ativos, mas antes no maisvalor por eles proporcionado - impondo assim novas mediações na relação entre o valor do capital efetivamente investido pela empresa e o preço das ações por ela emitidas - essa transformação constitui um passo importante em direção à efetiva autonomização do capital acionário. Como, porém, o mais-valor já apropriado pela 
empresa em geral depende do valor investido no processo de produção e circulação, a nova abordagem ainda não é capaz de levar esse processo a seus limites máximos.

Por isso mesmo, o desenvolvimento do capital acionário enquanto forma autonomizada do capital só foi concluído no século XX, quando os investidores passaram finalmente a adotar métodos de precificação de ações baseados não mais nos rendimentos historicamente observados, mas na estimação do valor presente dos rendimentos que - espera-se - seu proprietário auferirá no futuro. Essa transição, que ganhou corpo nos EUA principalmente na década de 1920, foi parcialmente interrompida nas três décadas seguintes, quando as incertezas geradas pela crise econômica e pela conflagração mundial induziram os investidores a adotar novamente métodos mais conservadores de precificação. A partir da década de 1950, porém, métodos de precificação das ações ancorados no cálculo do valor presente dos rendimentos aos quais seus proprietários terão direito no futuro começaram a ser adotados com uma velocidade cada vez maior pelos agentes responsáveis pela circulação desses ativos financeiros (Rutterford, 2004).

Para que isso viesse a ocorrer, foram de crucial importância as transformações institucionais que tiveram lugar nos EUA ainda na década de 1930, quando Roosevelt aproveitou-se da baixa popularidade de Wall Street para impor sobre os mercados de capitais uma série de normas que visavam controlar suas atividades potencialmente destrutivas. Como se sabe, entre essas medidas se inclui o Glass-Steagal Act, que deu ao Federal Reserve um grau de controle nunca antes visto sobre a atividade especulativas das instituições financeiras e estabeleceu uma demarcação clara entre as atividades dos bancos de investimento, seguradoras e bancos comerciais, restringindo a atividade especulativa e drenando, por conseguinte, a liquidez dos mercados acionários - o que por sua vez impôs um importante obstáculo ao processo de descolamento dos preços das ações em relação ao valor dos ativos pertencentes às empresas. Cabe notar, porém, que a administração Roosevelt também foi responsável por impulsionar a criação de normas contábeis uniformes (cuja inexistência facilitava a manipulação dos resultados financeiros das corporações, atrapalhando a projeção dos rendimentos futuros) e por impor às empresas listadas em bolsa a obrigação de divulgar mais e melhores informações a respeito de suas atividades (Baskin; Miranti Jr., 1999, p. 197-203), o que por sua vez elevou a transparência dos assuntos corporativos e criou as condições sem as quais o desenvolvimento ulterior das técnicas de precificação dos ativos financeiros emitidos pelas firmas seria impensável (Rutterford, 2004). Mais ainda: ela ajudou a criar a legislação que delimitaria as responsabilidades da burocracia corporativa e dos agentes responsáveis pela circulação dos ativos financeiros perante os investidores, medida sem a qual a massificação dos mercados financeiros observada na segunda metade do século XX não poderia ter ocorrido (Miranti, 1989). 
Eis então que, longe de apenas impor obstáculos ao desenvolvimento desse processo, a administração Roosevelt na verdade ajudou a pavimentar o caminho que levaria a autonomização do capital acionário a seus limites máximos (Panitch; Gindin, 2013). Não por acaso, o processo de dissociação do movimento do capital acionário em relação ao capital efetivamente investido na produção e circulação de mercadorias atingiu dimensões relevantes já nos anos 1960 - portanto, muito antes da remoção das medidas que compõem o Glass-Steagal -, como testemunham a generalização do uso de métodos de precificação baseados na estimação do crescimento futuro das empresas (Rutterford, 2004) e o considerável crescimento da razão P/L observado no período (Smith, 2003). E isso mostra que, mais do que o seu nascimento, o que as décadas seguintes - nas quais, como vimos, foi levada a cabo a assim chamada desregulamentação, um complexo processo de reconfiguração institucional que deve ser interpretado como o resultado não intencional das ações dos agentes nele envolvidos - presenciaram foi na verdade a intensificação e a conclusão de um processo de autonomização cuja origem remonta a um período anterior.

Pois bem: como pode ser depreendido da breve descrição do processo histórico de autonomização do capital acionário empreendida acima, a instauração das condições necessárias ao desenvolvimento e à conclusão desse processo em geral não dependeu da vontade e das intenções imediatas dos sujeitos diretamente envolvidos. Com efeito, o processo histórico de autonomização do capital acionário foi fruto da atuação de indivíduos cuja intenção não era, de maneira alguma, promover o descolamento dos movimentos do capital acionário em relação ao processo efetivo de produção e circulação de mercadorias. E se é assim, então uma interpretação ancorada primordialmente nas vontades e intenções dos agentes envolvidos não pode oferecer uma explicação adequada desse processo. É necessário, pelo contrário, desenvolver uma interpretação que dê conta do fato de que, em boa medida, o processo em tela se realizou apesar das inclinações pessoais dos indivíduos envolvidos.

Ora, isso é precisamente o que a abordagem desenvolvida por Marx ao problema da relação entre agência e estrutura numa economia capitalista nos permite fazer. Como vimos, Marx mostrou que, nas sociedades em que domina o modo de produção capitalista, as formas sociais funcionais ao processo de reprodução ampliada do capital tendem a se desenvolver e reproduzir espontaneamente através das ações apenas parcialmente conscientes dos indivíduos. Mais ainda: ele mostrou que o capital acionário é uma das formas imanentes ao modo de produção capitalista, sugerindo assim que essa forma - cujos movimentos refletem não as determinações do processo efetivo de produção e circulação de mercadorias, mas sim o valor descontado do mais-valor que, espera-se, o capital extrairá no futuro - tende a emergir nas sociedades capitalistas de maneira espontânea, isto é, 
independentemente da consciência e das intenções imediatas dos indivíduos cuja atuação concorre para este fim. Percebe-se assim que a abordagem desenvolvida por Marx nos permite desenvolver uma interpretação do processo histórico de autonomização do capital acionário mais coerente com os fatos do que aquela geralmente encontrada na literatura. E isso sugere que, longe de constituir um resultado meramente contingente das decisões aparentemente autônomas dos indívuos, a emergência histórica do capital acionário autonomizado consiste, pelo contrário, num resultado necessário do desenvolvimento histórico do modo de capitalista.

\section{Considerações finais}

Como o presente artigo visou demonstrar, a autonomização do capital acionário em relação ao circuito efetivo de produção e extração de mais-valor, condição sine qua non do recente processo de financeirização da firma, deve ser compreendida como um resultado necessário do próprio desenvolvimento do capitalismo. É importante ressaltar, porém, que isso não significa que o processo efetivo de financeirzação possa ser simplesmente deduzido do desenvolvimento do conceito de capital. Pelo contrário, não se deve jamais perder de vista a diferença entre a exposição conceitual do capital e a sua análise histórica (Fulda, 1974).

Foi o próprio Marx (1974, p. 945) quem ressaltou a importância da compreensão dos limites do método de exposição por ele adotado. Tais limites, cabe notar, têm sua origem não no método, mas no próprio objeto de estudo. De fato, na mesma medida em mostra que o desenvolvimento das formas imanentes ao capital coincide com o "desenvolvimento [do capital] em direção à totalidade" (Marx, 2004, p. 203), a exposição conceitual empreendida por Marx revela também que o capital é constitutivamente incapaz de levar a termo esse processo. Isso fica claro, por exemplo, no desenvolvimento da categoria do juro: esta, como vimos, é uma forma que necessariamente emerge da dinâmica capitalista; sua magnitude, no entanto, depende de determinaçõe exteriores ao capital enquanto tal, e, portanto não pode ser derivada da própria exposição conceitual. Evidencia-se, assim, que a totalidade constituída pelo capital é necessariamente aberta, do que se deduz que, longe de ser plenamente autodeterminado, o devir histórico do modo de produção capitalista está sujeito a determinações que ele mesmo é incapaz de controlar.

Isso o evidencia o próprio processo histórico de financeirização. Com efeito, se o desenvolvimento conceitual demonstra a necessidade da autonomização do capital acionário, o mesmo não pode ser dito a respeito de um fator que contribuiu sobremaneira para a intensificação do processo de financeirização: a inflação dos preços dos ativos financeiros que caracterizou o capitalismo da segunda metade do século XX. De tal fenômeno, a exposição conceitual não é capaz de revelar mais do que a possibilidade abstrata. Caberá, pois, à análise propriamente histórica desvendar 
as forças, processos e conflitos que concorreram para a realização efetiva dessa possibilidade, levando assim a cabo uma tarefa sem a qual a interpretação do processo histórico de financeirização da firma e do investimento estará necessariamente incompleta.

\section{Bibliografia}

AGLIETTA, M. Shareholder value and corporate governance: some tricky questions. Economy and Society, v. 29, n. 1, p. 146-159, 1 jan. 2000.

AGLIETTA, M.; REBERIOUX, A. Corporate governance adrift: a critique of shareholder value. il. ed. Cheltenham; Northampton, MA: Edward Elgar Pub, 2005.

BARAN, P.; SWEEZY, P. M. Capitalismo monopolista: ensaio sobre a ordem econômica e social americana. Rio de Janeiro: Zahar, 1978.

BASKIN, J. B.; MIRANTI JR., P. J. M. A history of corporate finance. Revised ed. Cambridge, U.K.; New York: Cambridge University Press, 1999.

BERLE, A.; MEANS, G. A moderna sociedade anônima e a propriedade privada. São Paulo: Abril Cultural, 1984.

BOYER, R. From shareholder value to CEO power: the paradox of the $1990 \mathrm{~s}$. Competition \& Change, v. 9, n. 1, p. 7-47, 1 mar. 2005.

CECCHETTI, S. G.; SCHOENHOLTZ, K. L. Money, banking and financial markets. 4. ed. New York: McGraw-Hill Education, 2014.

CHANDLER, A. D. The visible hand: the managerial revolution in American business. Unknown ed. Cambridge, Mass.: Belknap Press: An Imprint of Harvard University Press, 1993.

CHESNAIS, F. Mundialização financeira e vulnerabilidade sistêmica. In: CHESNAIS, F. (Org.). A mundialização financeira: gênese, custos e riscos. São Paulo: Xamã, 1998. p. 11-34.

CHESNAIS, F. O capital portador de juros: acumulação, internacionalização, efeitos econômicos e políticos. In: CHESNAIS, F. (Ed.). A finança mundializada. São Paulo: Boitempo Editorial, 2006. p. 35-67.

CROTTY, J. The neoliberal paradox: the impact of destructive product market competition and impatient finance on nonfinancial corporations in the neoliberal era. Review of Radical Political Economics, v. 35, n. 3, p. 271-279, 1 set. 2003.

CROUCH, C. Privatised Keynesianism: an unacknowledged policy regime. The British Journal of Politics \& International Relations, v. 11, n. 3, p. 382-399, 1 ago. 2009. 
DALLERY, T. Post-keynesian theories of the firm under financialization. Review of Radical Political Economics, v. 41, n. 4, p. 492-515, 1 dez. 2009.

D’ARISTA, J. The evolving international monetary system. Cambridge Journal of Economics, v. 33, n. 4, p. 633-652, 1 jul. 2009.

DAVIS, G. Managed by the markets: how finance re-shaped America. Reprint ed. Oxford; New York: Oxford University Press, 2011.

DAVIS, G. F.; STOUT, S. K. Organization theory and the market for corporate control: a dynamic analysis of the characteristics of large takeover targets, 19801990. Administrative Science Quarterly, v. 37, n. 4, p. 605-633, 1992.

DUMÉNIL, G.; LÉVY, D. The crisis of neoliberalism. Reprint ed. [s.1.] Harvard University Press, 2013.

DUNN, S. P. The economics of John Kenneth galbraith: introduction, persuasion, and rehabilitation. Cambridge; New York: Cambridge University Press, 2010.

EPSTEIN, G. A. Financialization and the world economy. Cheltenham, UK; Northampton, MA: Edward Elgar Publishing, 2006.

FINE, B. Financialization from a Marxist perspective. International Journal of Political Economy, v. 42, n. 4, p. 47-66, Winter 2013.

FLIGSTEIN, N.; SHIN, T. Shareholder value and the transformation of the U.S. economy, 1984-2001. Sociological Forum, v. 22, n. 4, p. 399-424, 1 dez. 2007.

FOURCADE, M. Theories of markets and theories of society. American Behavioral Scientist, v. 50, n. 8, p. 1015-1034, 1 abr. 2007.

FULDA, H. These zur Dialektik als Darstellungsmethode (im "Kapital” vom Marx). In: Hegel-Jahrbuch. [s.1.] Pahl-Rugenstein Verlag, 1974.

GALBRAITH, J. K. O novo estado industrial. Rio de Janeiro: Civilização Brasileira, 1968.

HARCOURT, B. E. Illusion of free markets. Harvard University Press, 2012.

HEINRICH, M. Die Wissenschaft vom Wert: die Marxsche Kritik der Politischen Ökonomie zwischen wissenschaftlicher revolution und klassischer Tradition 5. Auflage ed. [s.1.] Westfälisches Dampfboot, 2011.

HELLEINER, E. States and the reemergence of global finance: from Bretton Woods to the 1990s. Ithaca, NY: Cornell University Press, 1996.

HELLEINER, E. The return of regulation, and what a difference a decade makes. Disponível em: http://www.theglobeandmail.com/opinion/the-return-of-regulationand-what-a-difference-a-decade-makes/article1061635/. Acesso em: 19 mar. 2017. 
HILFERDING, R. Finance capital: a study of the latest phase of capitalist development. Tradition Morris Watnick; Sam Gordon. London ; Boston: Routledge \& Kegan Paul, 1981.

KINDLEBERGER, C. P. A financial history of western Europe. 2. ed. New York: Oxford University Press, 1993.

KONINGS, M. Rethinking neoliberalism and the subprime crisis: beyond the reregulation agenda. Competition \& Change, v. 13, n. 2, p. 108-127, 1 jun. 2009.

KRIPPNER, G. R. The financialization of the American economy. Socio-Economic Review, v. 3, n. 2, p. 173-208, 1 maio 2005.

KRIPPNER, G. R. Capitalizing on crisis: the political origins of the rise of finance. Cambridge, Mass.; London: Harvard University Press, 2012.

KRUGMAN, P. Moral decay? Or deregulation? Disponível em: https://krugman.blogs.nytimes.com/2009/09/30/moral-decay-or-deregulation/.

Acesso em: 19 mar. 2017.

LANGLEY, P. The everyday life of global finance: saving and borrowing in AngloAmerica. Oxford; New York: OUP Oxford, 2009.

LAPAVITSAS, C. Profiting without producing: how finance exploits us all. London; New York: Verso Books, 2013.

LAVOIE, M. Post-Keynesian economics: new foundations. [s.1.] Edward Elgar Pub, 2015.

LAZONICK, W.; O'SULLIVAN, M. Maximizing shareholder value: a new ideology for corporate governance. Economy and Society, v. 29, n. 1, p. 13-35, 1 jan. 2000 .

LEYSHON, A.; THRIFT, N. The capitalization of almost everything - The future of finance and capitalism. Theory, Culture \& Society, v. 24, n. 7-8, p. 97-115, dez. 2007.

LUKÁCS, G. História e consciência de classe. Tradução de Rodinei Nascimento. 2. ed. [s.1.] WMF Martins Fontes, 2012.

MARX, K. Das Kapital: Kritik der Politischen Oekonomie. Hamburg : O. Meissner; New York: L. W. Schmidt, 1867.

MARX, K. Briefe an Engels 2. April 1858. In: Marx und Engels Werke Bd. 29 Briefe Januar 1856 - Dezember 1859. Berlin: Dietz, 1970. p. 311-318.

MARX, K. Grundrisse der Kritik der Politischen Ökonomie (Rohentwurf). 18571858, Anhang 1850-1859. 2. ed. [s.1.] Dietz, 1974.

MARX, K. O capital: crítica da economia política. (Livro Primeiro, v. 2). Trad. de Flávio Kothe. São Paulo: Nova Cultural, 1983a. 
MARX, K. O capital: crítica da economia política. (Livro Primeiro, v. I). Trad. de Flávio Kothe. São Paulo: Nova Cultural, 1983b.

MARX, K. O capital: crítica da economia política. (Livro Terceiro, v. I). Trad. de Flávio Kothe. São Paulo: Nova Cultural, 1985.

MARX, K. MEW: Werke, 43 Bde., Bd.42, Ökonomische Manuskripte 1857-1858. Berlim: Dietz Verlag, 2004.

MARX, K.; ENGELS, F. A sagrada família: ou a crítica da Crítica crítica: contra Bruno Bauer e consortes. São Paulo: Boitempo Editorial, 2015.

MIRANTI, P. J. The mind's eye of reform: the ICC's bureau of statistics and accounts and a vision of regulation, 1887-1940. Business History Review, v. 63, n. 3, p. 469-509, Oct. 1989.

MIROWSKI, P. Never let a serious crisis go to waste: how neoliberalism survived the financial meltdown. London; New York: Verso Books, 2013.

MONTGOMERIE, J. Bridging the critical divide: global finance, financialisation and contemporary capitalism. Contemporary Politics, v. 14, n. 3, p. 233-252, 2008.

NORFIELD, T. The city: London and the global power of finance. London, United Kingdom. Verso Books, 2016.

PANITCH, L.; GINDIN, S. The making of global capitalism: the political economy of American empire. London ; Brooklyn, NY: Verso Books, 2013.

PECK, J. Constructions of neoliberal reason. Reprint ed. Oxford: Oxford University Press, USA, 2013.

PETIT, P. Managerial capitalism by any other name. Challenge, v. 48, n. 5, p. 6278, 1 out. 2005.

RUSSELL, E. New deal banking reforms and keynesian welfare state capitalism. $1^{\text {st }}$ ed. New York: Routledge, 2007.

RUTTERFORD, J. From dividend yield to discounted cash flow: a history of UK and US equity valuation techniques. Accounting, Business \& Financial History, v. 14, n. 2, p. 115-149, Jul. 2004.

SAES, F. A. M. DE; SAES, A. M. História Econômica Geral. $1^{\text {st }}$ ed. [s.1.] Saraiva, 2013.

SLOAN, R. G. Do stock prices fully reflect information in accruals and cash flows about future earnings? The Accounting Review, v. 71, n. 3, p. 289-315, 1996.

SMITH, B. M. Toward rational exuberance: the evolution of the modern stock market. $1^{\text {st }}$ ed. New York: Farrar Straus Giroux, 2001. 
SMITH, B. M. The equity culture: the story of the global stock market. $1^{\text {st }}$ ed. New York: Farrar, Straus and Giroux, 2003.

STIGLITZ, J. How to get out of the financial crisis. Time, 17 Oct. 2009.

STOCKHAMMER, E. Financialisation and the slowdown of accumulation. Cambridge Journal of Economics, v. 28, n. 5, p. 719-741, 1 Sept. 2004.

STOCKHAMMER, E.; LAVOIE, M. (Ed.). Wage-led growth: an equitable strategy for economic recovery. 1st ed. New York, Palgrave Macmillan, 2013.

TOPOROWSKI, J. The economics and culture of financial inflation. Competition \& Change, v. 13, n. 2, p. 145-156, Jun. 2009.

USEEM, M. Investor capitalism. New York: Basic Books, 1999.

WADE, R. Financial regime change? New Left Review, v. 2, n. 53, p. 5-21, 2008.

WOLF, D. Semantik, Struktur und Handlung im „kapital“. Disponível em: http://dieterwolf.net/wp-content/uploads/2016/02/Semantik_Struktur_und_ Handlung_im_Kapital.pdf. Acesso em: 23 mar. 2017.

ZAJAC, E. J.; WESTPHAL, J. D. The social construction of market value: institutionalization and learning perspectives on stock market reactions. American Sociological Review, v. 69, n. 3, p. 433-457, 1 Jun. 2004. 